\title{
VENTURE CREATORS AND FIRM BUYERS: A COMPARISON OF ATTITUDES TOWARDS GOVERNMENT HELP AND LOCUS OF CONTROL
}

\section{Jean-Charles Cachon,}

Laurentian University of Sudbury

\begin{abstract}
The relationship between the business-formation process and the use of government or outside counselling is examined, by differentiating, among a total group of 78 small-firm owners, between those who created their ventures and those who bought them. The group of venture initiators was found as having requested government help in one-third of the start-ups, while none of the business buyers had resorted to such support. At the same time, the first group displayed a more internal locus of control disposition than the other, thus reinforcing earlier findings about entrepreneurs. Both groups, however, were strongly internal-oriented compared to general populations.

SOMMAIRE

À partir d'un groupe de propriétaires, créateurs ou acquéreurs, de petites entreprises, l'auteur établit le rapport entre le processus d'établissement et le recours au counselling gouvernemental ou extérieur. On constate que le tiers des propriétaires qui ont créé leur entreprise ont demandé l'aide du gouvernement, contre aucun parmi ceux qui s'en sont portés acquéreurs. On a également constaté que le premier groupe avait une nette tendance à établir le siège du contrôle à l'intérieur des structures comparativement aux autres, ce qui renforce les constatations précédentes au sujet des entrepreneurs. Toutefois, les deux groupes à l'étude mettaient un accent beaucoup plus prononcé sur le contrôle interne que le reste des entreprises.
\end{abstract}

\section{OBJECTIVES OF THE STUDY}

Carland et al. (1) point out that individuals who establish a business and operate it should be distinguished from those who simply own one. It is also reported that entrepreneurs tend to display a negative attitude toward government programs geared to them, mostly complaining about the low return they get from their investment in time, paperwork and red tape. The purpose of this study is to investigate if a difference of attitude toward government help can be found between venture creators and those who have bought their firm (presumably having assumed less risk). The difference between the two groups is also measured according to a concept frequently used in the literature to describe entrepreneurs: internal vs external locus of control.

\section{CONTEXT}

Following a change in policy towards the development of the economy of Northern Ontario on the part of the provincial government, mostly in the direction of helping Northerners to develop economically through starting business enterprises (a direction already followed in countries such as Ireland (2), it appeared appropriate to evaluate the feeling of the business community regarding the role of government as a facilitator. The bulk of research conducted by the government of Ontario in this respect deals with the province as a whole, therefore blending results about Northern Ontario with the rest of the province. The overall effect being that, due to the rapid growth Southern Ontario has been undergoing since 1983, the "Northern problem" often remains difficult to pinpoint. One of the objectives of the 
present research was therefore to identify in which way the business community of Northern Ontario tends to react towards government in its role of enhancing the small-business sector.

Since 1987, with the decision to create centres of entrepreneurship within universities and community colleges in Ontario, policy-makers appear to recognise the importance of the small-business sector as a job-creation setting. In such a context, it seems important to identify in which way individuals who initiate new ventures differ from those who buy an ongoing concern and manage it. This study attempted to do so with regard to the attitudes of two groups of business owner/managers - one having launched their businesses, the other having acquired existing ones.

\section{ENTREPRENEURIAL CHARACTERISTICS}

The entrepreneur is generally described as a person having strong persuasive powers, capable of initiative, creativity and flexibility, able to lead others towards goals requiring moderate risk-taking, displaying a strong need to control environment and to achieve, as well as the capability to work hard and persistently, to be imaginative and to be able to solve problems (3). All those characteristics, while being generally accepted as the descriptors of an entrepreneurial personality, cannot be measured easily. However, the need to control one's own environment has been repeatedly described as a critical entrepreneurial characteristic by researchers in the field (4) (5) and, therefore, can be used as a proxy measure to differentiate entrepreneurs from a more general population when, as in this instance, the constraints faced by the researcher prevent the use of a more complete set of instruments.

The concept of locus of control suggests a dichotomy between individuals who have the feeling of being able to reach goals by controlling their environment (internal locus of control), opposed to those individuals who rather see their life as depending a lot on chance and events occurring in their environment (external locus of control). While no individual will display all the characteristics of either of the opposites, previous research has shown entrepreneurs as having, in general, a significantly stronger internal locus of control than the general population. The ability to take moderate (controllable) risks and a strong desire to achieve have been related to this orientation among entrepreneurs.

No attempt has been made in this study to use a mediating factor such as the level of profitability to identify the effect upon the attitudes investigated. Small businesses usually are difficult to compare in these terms due to the structure of the Canadian Income Tax Act and the accounting principles accepted in the country. At best, the number of employees can be used as a proxy measure of success.

\section{HYPOTHESES}

Two major hypotheses were tested:

1. Venture creators tend to assume a larger amount of risk than existing-firm buyers and, therefore, are more prone to engage into activities that may reduce the risk, such as trying to obtain government assistance in some way. On the other hand, the buyer of an existing business can plan the future more easily with the knowledge of the past history of the company, relying in a much lower extent to government help. We can therefore hypothesize that venture creators will be more frequent users of government help and will display a more positive attitude toward it than business buyers.

2 . The desire for control of one's own future is repeatedly described as one of the major characteristics of entrepreneurs; this characteristic, as measured by locus of control attitudinal scales, usually shows entrepreneurs displaying stronger internal locus of control orientations than others. It is hypothesized that venture creators tend to show stronger entrepreneurial characteristics than business buyers (i.e. a stronger internal locus of control orientation than their counterparts). 


\section{METHOD}

\section{INSTRUMENT}

A questionnaire divided into two sections has been used: the first part includes questions regarding the history of the firm, its size, and the owner/manager's attitudes toward government help geared to small business; the second part of the questionnaire is made of the Rotter Internal-External locus of control scale (6). A reliability analysis on the latter yielded a Cronbach's alpha level of 0.59 .

\section{SAMPLE}

A total of 81 owner/managers of small- and medium-sized companies (up to 250 employees) across Northern Ontario participated in a mail survey during the spring and summer of 1987. One hundred and fifty names were randomly picked-up from chamber of commerce listings in five cities, yielding a 54 per cent response rate. The availability of government programs and types of help has been the same across the region for the past 30 years, as well as its economic fluctuations, thus securing a homogeneity of the environment. A pilot study with a smaller sample within the city of Sudbury had been conducted in early 1987, through direct interviews involving 20 business owners.

\section{ANALYSIS}

The first hypothesis was tested by the differences in proportions of respondents having either a recollection of having previously benefited from government counselling or help, or planning to seek such assistance in the future. One way analyses of variance between groups were used to test the second hypothesis in relation to the dimensions explored among the sample under study. The SPSS-X package was used to analyze the data.

\section{RESULTS}

\section{SAMPLE DESCRIPTION}

The frequencies are presented on Table 1 and show that 67 per cent of the sample includes business initiators, or "true" entrepreneurs, while 30 per cent had bought an existing venture. The remaining 3 per cent were excluded from further analyses, as they were managers of government-funded agencies. Most of the respondents had been in the current business for more than 10 years ( 84 per cent).

Regarding their economic sectors, 29 per cent of the initiators were involved in retailing, 65 per cent in other services, and 6 per cent in manufacturing; the proportions for buyers were respectively of $37.5,37.5$, and 25 per cent.

About half of the respondents had had some previous business experience, the proportion being higher among the initiators ( 41 per cent) than the buyers ( 25 per cent). However, both groups had more than two years experience in the current sector (in 75 per cent of the cases) prior to venturing into their current business.

\section{ANALYSIS}

Hypothesis 1: While none of the buyers had relied upon outside consulting to start, 35 per cent of the initiators had sought some form of external help, either private, governmental or both. Should they decide to expand or start a new venture, 88 per cent of the initiators declared themselves ready to look for external help (but only 12 per cent would seek government consulting only, and 35 per cent a mix of private and government counselling), while 62.5 per cent of the buyers thought external help would be appropriate ( 25 per cent looking for government counselling, the remainder preferring private help). Those results appear to confirm our first hypothesis: venture initiators tend to be willing to reduce the amount of risk inherent to a start-up by seeking outside counsel and reinforcement, while buyers rely mostly upon past performance to predict their own chances of future success. 
Table 1

Sample Overview

$\begin{array}{lrc}\text { 1. Launched the business } & 11 & \% \\ \text { Acquired current venture } & 24 & 0.67 \\ \text { Non applicable/no answer } & 3 & 0.30 \\ \end{array}$

2. Prior business start-ups:

30

.03

Initiators

21

None
One or more

3. Previous experience in current type of business:

\begin{tabular}{lc} 
None & Initiators \\
Two to five years & 12 \\
Over five years & 9 \\
\hline
\end{tabular}

Over five years

(20.7)

Buyers Total

$\begin{array}{lll}\text { n } & \% \\ 6 & 39 & 0.52\end{array}$

4. Have you sought the advice of a consultant for starting up?

None

Private firm

Government-funded

Both types of consulting

Buyers Total

$\begin{array}{lll}6 & 18 & 0.24 \\ 3 & 12 & 0.16\end{array}$

$15 \quad 45 \quad 0.60$

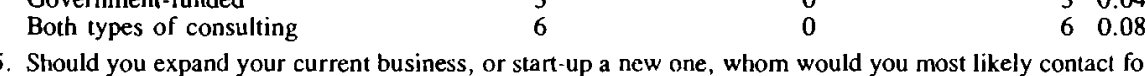

Initiators $\quad$ Buyers $\quad$ Total

$\begin{array}{lrrrr}\text { None } & 6 & 9 & 15 & 0.20 \\ \text { Private firm } & 21 & 9 & 30 & 0.40 \\ \text { Government funded } & 6 & 6 & 12 & 0.16\end{array}$

Both types of consulting

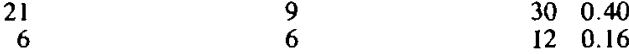

$\begin{array}{rrrr}6 & 6 & 12 & 0.16 \\ 18 & 0 & 18 & 0.24\end{array}$

6. Has your current business ever bencfited from any form of direct government assistance?
Yes
Initiators
Buyers
18
$\begin{array}{rr}21 & 18 \\ 30 & 6\end{array}$
Total
$39 \quad 0.52$

$\begin{array}{ll}18 & 0.24\end{array}$

No

$\begin{array}{ll}36 & 0.48\end{array}$

7. If you knew the government just introduced a program to help your line of business, whom would you contact?

$\begin{array}{llrrr}\text { Accountant/lawyer } & 24 & 12 & 36 & 0.48 \\ \text { Government ministry } & 27 & 9 & 36 & 0.48\end{array}$

Other*

*F.B.D.B., local politician, private consultant.

$\begin{array}{rr}36 & 0.48 \\ 3 & 0.04\end{array}$

8. What do you perceive as your primary motive to be in business?

\begin{tabular}{|c|c|c|c|c|}
\hline & Initiators & Buyers & & tal \\
\hline Be your own boss & 9 & 9 & 18 & 0.24 \\
\hline Offer better product/service & 12 & 3 & 15 & 0.20 \\
\hline Financial independance & 21 & 3 & 24 & 0.32 \\
\hline Escape frustrations of previous job & 0 & 3 & 3 & 0.04 \\
\hline Other motive & 9 & 6 & 15 & 0.20 \\
\hline How many employees (full-time equ & ent) do prt & or your $b$ & & \\
\hline & Initiators & Buyers & & tal \\
\hline Less than 10 & 3 & 3 & & 0.08 \\
\hline 10 to 25 & 15 & 6 & 21 & 0.28 \\
\hline 26 to 50 & 9 & 3 & 12 & 0.16 \\
\hline over 50 & 24 & 12 & 36 & 0.48 \\
\hline How long have you been in busines & & & & \\
\hline & Initiators & Buyers & & tal \\
\hline Less than 5 years & 3 & 0 & & 0.04 \\
\hline 6 to 10 years & 9 & 0 & 9 & 0.12 \\
\hline 11 to 20 years & 15 & 6 & 21 & 0.28 \\
\hline Over 10 years & 24 & 18 & 42 & 0.56 \\
\hline
\end{tabular}

11. Have you ever had marketing research studies conducted to determine how you could better serve or attract new customers?
Yes
Initiators

Buyers

Total

$\begin{array}{llll}\text { No } & 33 & 30 & 0.40\end{array}$

12. What form of business organization do you presently have?

\begin{tabular}{ccccc} 
& Initiators & Buyers & \multicolumn{1}{c}{ Total } \\
Corporation & 36 & 15 & 510.68
\end{tabular}

Parnership

9

512

13. What business sector are you presently in?

Retail Initiators

Services

Buyers

Total

Manufacturing

33

\begin{tabular}{ll}
24 & 0.32 \\
42 & 0.56 \\
\hline
\end{tabular}

\begin{tabular}{rr}
9 & 0.12 \\
\hline
\end{tabular}

44 
A further set of questions dealt with whether the owner/managers recalled having received some form of government help in the past. While only 41 per cent of the initiators felt so, 75 per cent of the buyers declared having benefited from direct government assistance during their tenure with the business. When asked who they would approach about new government programs to help their business sector, only 37.5 per cent of the buyers would approach government officials, while 52 per cent of the initiators would do so, thus reinforcing the above results.

Hypothesis 2: A one-way analysis of variance was conducted in order to identify differences in locus of control scores between initiators and buyers (Table 2). The Rotter scale scores of 17.5 and 15.9 respectively for initiators and buyers were significantly different at $p<0.01$ between the two groups, thus confirming the hypothesis that venture creators display a more internal locus of control orientation than those who bought their current business. The same type of analysis was then reproduced to compare other types of groupings among the sample, yielding a number of significant differences according to various groupings. In all groupings, however, results were significantly higher than the scores reported by Rotter among more general populations $(5.48$ to 10.00$)(7)$.

Table 2

One Way Analysis of Variance Between

Rotter's Locus of Control Scale Scores and Some of the Variables

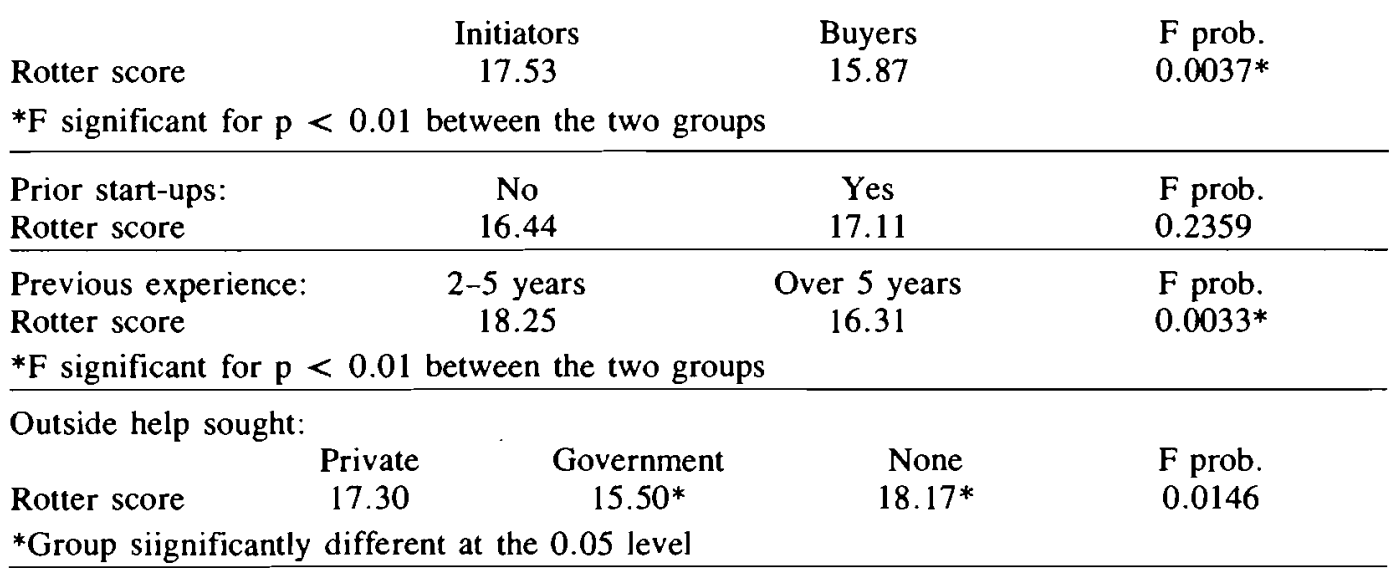

Motives for entrepreneurship:

$\begin{array}{lcccc} & \text { Better } & \text { Frustrated } & \text { Money } & \text { F prob. } \\ \text { Rotter score } & 17.80 & 11.00^{*} & 17.37 & 0.0001\end{array}$

*Group significantly different at the 0.05 level

\begin{tabular}{|c|c|c|c|c|}
\hline \multicolumn{5}{|l|}{ Number of employees: } \\
\hline $\begin{array}{cc} & 10 \\
\text { Rotter score } & 14.67^{*}\end{array}$ & $\begin{array}{l}11-25 \\
16.29\end{array}$ & $\begin{array}{l}26-50 \\
17.75\end{array}$ & $\begin{array}{c}50 \\
17.50\end{array}$ & $\begin{array}{l}\text { F prob. } \\
0.0290\end{array}$ \\
\hline \multicolumn{5}{|c|}{${ }^{*}$ Group significantly different from the last two groups at the 0.05 level } \\
\hline \multicolumn{5}{|l|}{ Number of years in business: } \\
\hline & $5-10$ & $11-20$ & 20 & F prob. \\
\hline$\underline{\text { Rotter score }}$ & 17.00 & 17.57 & 16.43 & 0.2645 \\
\hline \multicolumn{5}{|l|}{ Marketing research: } \\
\hline & Some & & & F prob. \\
\hline Rotter score & 14.91 & & & $0.0000^{*}$ \\
\hline *Score difference significant & & & & \\
\hline
\end{tabular}


Those owners with less than five years previous experience in the business prior to start-up displayed a stronger internal locus of control orientation than those having more than five-years experience $(18.2$ compared to 16.3 scores at $p<0.01)$. When separating the sample between those who sought government assistance before and those who did not, another significant difference was found, the latter group being more internally oriented than the former $(18.2$ against 15.5 scores at $p<0.02)$; however, those having strictly relied upon private consulting were not different (score of 17.3). This result suggests the existence of two categories of people among the venture initiators: a first group with a strong internal locus of control, who is not resorting to public assistance, and a second group of initiators who have obtained government help and display a lesser level of internal locus of control.

\section{DISCUSSION}

\section{TO BE HELPED OR NOT TO BE}

The results regarding the first hypothesis are consistent with the literature and show that venture initiators (or "true" entrepreneurs) had a tendency to try to reduce their risks by seeking public assistance, while their business-buying counterparts had not decided to do so. Further studies should examine in more depth the reasons for those differences, possibly longitudinally with the use of qualitative research methods, such as repeated, semistructured interviews.

Following several interviews with small-firm owners, Curran (8) observed a tendency to shy away from government programs because of a distrust of most communications emanating from governments, thus neutralizing the effects of the publicity for the programs. Such attitudes usually do not appear in structured questionnaire surveys, where the desire to remain independent or the fear of bureaucracy are often given as reasons not to benefit from government programs.

Most of the businesses surveyed in this study remained relatively small. At the same time, government programs aimed at smaller businesses often promote expansion through further staffing, thereby fulfilling a job-creation objective. However, evidence from previous research (9) suggests that expansion may not be an objective among many small-business owners, a finding which may be verified in various countries.

\section{LOCUS OF CONTROL}

Internal locus of control is verified again as a strong discriminator between business initiators compared to those who bought existing ones. This result confirms earlier findings regarding entrepreneurs compared to managers or to more general populations. However, this study seems to be the first to distinguish between the creators of a new business and buyers of existing ones. Such a result needs to be verified among populations outside Northern Ontario to be confirmed. If proven true, it would suggest opportunities for further research into the development of successful small firms, such as potential differences in the way an owner-created firm evolves and grows, comparatively to an owner-bought one, the way they are managed, and the way they react to product-market shifts.

\section{POLICY IMPLICATIONS OF THE STUDY}

The distinction between business initiators and buyers suggests that those two groups develop different attitudes over time towards government programs. In general, those who bought an existing business were less prone to have used government help in the past than those who initiated their present venture. If proven general across various regions, this result suggests that government programs may be more successful if aimed at businesscreating entrepreneurs than directed towards those who wish to invest in an existing business. However, the locus of control results indicate that, among our sample, 
entrepreneurs who resort to government help tend to display a rather low internal locus of control attitude, which contradicts one of the assumptions coming from past research about entrepreneurs. This suggests a possible need for program packages that would include some form of counselling aimed at helping entrepreneurs to feel more in control of their own future, as well as a need for civil servants trained on how to respond specifically to entrepreneurial needs (10).

\section{LIMITS OF THE STUDY}

There are two major limitations to the findings reported above: The sample was drawn from a region that has been economically depressed for a period of about 10 years at the time of the study. In such an environment, many attitudes towards government programs and interventions can be distorted and not representative of other regions of Ontario or Canada. However, such an environment is shared by some regions in various countries (Northern England, Southern Italy, the U.S. Midwest). Secondly, the method used to gather the data (survey-based) does not allow for an in-depth examination of the psychological and sociological complexities of the small business owner/manager, limiting itself to a punctual measure of a few predetermined attitudes at a given moment in time. It is suggested that further studies in the field should be more qualitative and longitudinal in nature, allowing for the use of instruments such as semi-structured interviews and unstructured tape-recorded conversations, thus allowing for interpretations followed by respondent validations.

\section{REFERENCES}

1. Carland, J.W., F. Hoy, W.R. Boulton, and J.A. Carland, "Differentiating entrepreneurs from small business owners: a conceptualization", Academy of Management Review, 1984, 9, 2, 354 to 359.

2. Byrne, P. and D.A. Cineen, "Developing small firms in a peripheral region Assessment of the state support system", Cranfield School of Management: Tenth National Small Firms Conference Proceedings, Cranfield, Bedford, 1987.

3. Gibb, A.A., "Enterprise culture - Its meaning and implications for education and training", Journal of European Industrial Training, 11, 2, 1987, 1 to 38.

4. Borland, C., Locus of Control, Need for Achievement and Entrepreneurship. Austin, Texas: Doctoral dissertation, University of Texas 1975.

5. Panday, J. and N.B. Tewary, "Locus of control and achievement values of entrepreneurs", Journal of Occupational Psychology, 1979, 52, 2, 107 to 111.

6. Rotter, J.B., "Generalized expectancies for internal versus external locus of control of reinforcement”, Psychological Monographs, 1966, 80, 1 (Whole No. 609), 260 to 295.

7. Ibid. 279 to 280

8. Curran, J., "Starting and surviving: some small firms in the 1980s", Cranfield School of Management: Tenth National Small Firms Conference Proceedings, Cranfield, Bedford, 1987.

9. Armstrong, P., A.M. Baker and J. Johnson, "Support Agencies in the enterprise culture: perceptions of small retailers", Cranfield School of Management: Tenth National Small Firms Conference Proceedings, Cranfield, Bedford, 1987.

10. Barnes, I. and J. Campbell, "Local authority economic intervention and the enterprise culture", Cranfield School of Management: Tenth National Small Firms Conference Proceedings, Cranfield, Bedford, 1987. 